\title{
Pengaruh Terpaan Media dan Daya Tarik Destinasi Wisata terhadap Minat Berwisata
}

\author{
T. Titi Widaningsih ${ }^{1 *}$, Yuli Nugraheni' ${ }^{2}$, E. Nugrahaeni Prananingrum ${ }^{3}$, \& Arry Rahayunianto ${ }^{4}$ \\ ${ }^{1}$ Sekolah Pascasarjana Universitas Sahid Jakarta, Sahid Sudirman Residence - Jl. Jend. Sudirman 56 \\ Jakarta 10220 \\ ${ }^{2}$ Universitas Katolik Widya Mandala Surabaya, Jl. Dinoyo 42-44 Surabaya 60265 \\ 3\&4Universitas Negeri Jakarta, Jl. R.Mangun Muka Raya, RT.11/RW.14, Rawamangun, Kec. Pulo Gadung, \\ Kota Jakarta Timur, Jakarta 13220 \\ *e-mail : titi_widaningsih@usahid.ac.id
}

\begin{abstract}
The world has entered the industrial era 5.0, when all aspects of human life are controlled by information technology. Society is changing and moving fast with technology to achieve a more meaningful life. The tourism industry has also developed following the development of industry 5.0 which is marked by the full digitization of the tourism sector. The way tourists travel is changing. The tourists will start their journey by looking for or seeing a variety of information (look), then proceed with the second step, namely ordering a tour package that is of interest (book) and the next part is the final stage, which is paying online (pay). Communication technology has changed the behavior of the tourism market towards digital. Tourist behavior is increasingly mobile, personal and interactive. Tourists can easily get tourist information with the availability and easy access to communication networks. Media with various tourist information have an influence on tourists to travel. In addition to communication media, the attractiveness of tourist destinations also affects tourists' choice of visiting tourist destinations. The purpose of this study was to determine the effect of media exposure and the attractiveness of tourist destinations on tourism interest. The research was conducted in the Betawi Cultural Tourism Area Setu Babakan, South Jakarta, Indonesia. The results showed that media exposure and tourist attraction influenced the interest in visiting tourist destinations.
\end{abstract}

Keywords: exposure, new media, destination attraction, interest in visiting.

\begin{abstract}
ABSTRAK
Saat ini dunia telah memasuki era industri 5.0, saat dimana seluruh sendi kehidupan manusia dikendalikan oleh teknologi informasi. Masyarakat berubah dan bergerak cepat dengan teknologi untuk mencapai kehidupan yang lebih bermakna. Industri pariwisatapun berkembang mengikuti perkembangan industri 5.0 yang ditandai dengan serba digitalisasi sektor pariwisata. Cara wisatawan melakukan perjalanan wisata berubah. Para wisatawan akan memulai perjalanannya dengan mencari atau melihat beragam informasi (look), kemudian akan dilanjutkan dengan langkah kedua yaitu memesan paket wisata yang diminati (book) dan bagian berikutnya adalah tahap akhir yaitu membayar secara online (pay). Teknologi komunikasi telah merubah perilaku pasar pariwisata kearah digital. Perilaku wisatawan semakin mobile, personal dan interaktif. Wisatawan dengan mudah mendapatkan informasi wisata dengan ketersediaan dan kemudahan akses terhadap jaringan komunikasi, Media dengan berbagai informasi wisata membawa pengaruh terhadap wisatawan untuk berwisata. Selain media komunikasi, daya tarik destinasi wisata juga mempengaruhi pilihan wisatawan untuk mengujungi destinasi wisata. Tujuan penelitian ini untuk mengetahui pengaruh terpaan media dan daya tarik destinasi wisata terhadap minat berwisata. Penelitian dilakukan di Kawasan Wisata Budaya Betawi Setu Babakan Jakarta Selatan, Indonesia. Hasil penelitian memperlihatkan terpaan media dan daya tarik wisata berpengaruh terhadap minat mengunjungi destinasi wisata.
\end{abstract}

Kata kunci: terpaan, media baru, daya tarik destinasi, minat berkunjung. 


\section{Latar Belakang}

Era industri 5.0 dimana peran manusia yang digantikan kehadiran teknologi yang cerdas yang mendegradasi peran manusia. Perkembangan teknologi melahirkan society 5.0, masyarakat yang berbasis teknologi. Masyarakat dimana kecerdasan buatan (artificial intelligence) akan mentransformasi big data pada segala sendi kehidupan serta the Internet of Things akan menjadi suatu kearifan baru, yang akan didedikasikan untuk meningkatkan kemampuan manusia membuka peluang baru. Masyarakat yang berpusat pada manusia (human-centered) dan berbasis teknologi (technology based).

Perkembangan teknologi komunikasi dan informasi di era industri 5.0 membawa pengaruh pada perkembangan pariwisata di Indonesia. Teknologi komunikasi telah merubah perilaku pasar pariwisata kearah digital dan perilaku konsumen yang semakin mobile, personal dan interaktif. Kementrian pariwisata republik Indonesia telah membuat program Go Digital sebagai program strategis untuk memenangkan pasar di era industri 5.0. Pengembangan pariwisata 5.0 dengan target pertumbuhan yang tinggi khususnya wisatawan milenial. Wisatawan milenial dengan karakteristik digital, mobile, personal serta interaktif.

Perkembangan industri 5.0 membawa pengaruh digitalisasi pada industri pariwisata. Hal ini juga terlihat dari perubahan perilaku konsumen ketika search and share, reservasi tiket, hotel dan memilih paket wisata, melakukan pembayaran semua dilakukan secara digital. Digitalisasi memudahkan wisatawan dalam melakukan perjalanan wisata. Ketersediaan dan kemudahan akses terhadap jaringan internet dan beragam aplikasi travel telah banyak dimanfaatkan oleh wisatawan. Pemanfaatan teknologi komunikasi dan informasi dalam industri pariwisata membawa implikasi terhadap terpaan media. Masyarakat tidak bisa terlepas dari terpaan media atau menerpakan diri terhadap media untuk mengakses informasi wisata.

Selain itu kondisi pandemic akibat wabah virus corona juga memaksa banyak negara untuk berpikir keras menanggulangi dampak di sektor wisata dengan pemanfaatan teknologi. Artikel Kompas Senin 14 Desember 2020 menuliskan Pulihkan Sektor Pariwisata Industri MICE Jadi Prioritas. Banyak pelaku industri pariwisata harus berinovasi dalam memanfaatkan teknologi untuk sarana promosi destinasi wisata mereka.

Salah satu destinasi wisata di wilayah Jakarta adalah Setu Babakan, Menurut catatan Kementrian Agraria dan Tata Ruang / BPN 2018 Setu Babakan menjadi salah satu dari 31 prioritas. Saat ini menurut data Litbang Kompas Setu Babakan menjadi salah satu setu yang belum memilii sertifikasi lahan. Kendati demikian kawasan Stu Babakan menjadi kawasan khusus budaya Betawi. Para pengunjung dapat dating dan menikmati sekaligus belajar budaya Betawi.Galeri, rumah adat dan panggung seni serta berbagai pertunjukan seni adat Betawi yang sering ditampilakan menjadi daya tarik pengunjung apalagi masyarakat masyarakat dapat memperoleh keuntungan ekonomi dari keberadaan obyek wisata Jakarta ini.Biasanya setiap peringatan ulang tahun kota Jakarta kawasan ini ramai dikunjungi. Penjual bir pletok, kerak telur, dodol Betawi, penjaja cinderamata hingga tukang parker turut memperoleh keuntungan.

Hal yang menarik dari obyek wisata Setu Babakan adalah perpaduan mitos dan budaya untuk pelestarian lingkungan alam

Setu ini terletak di Kelurahan Srengseng Sawah Jakarta Selatan dan 
menjadi pusat perkembangan udaya Betawi. Penetapan cagar budaya ini berlaku sejak Gubernur Sutiyoso menetapkan SK Gubernur No 92 Tahun 2000 tentang Penataan Lingkyungan Perkampungan Budaya Betawi.

Berikut adalah profil Kampung Betawi Setu Babakan: Luas area 289 hektar. Berdasarkan data dari Litbang Kompas dan laman Jakarta.go.id serta Jakartatourism.go.id, Kawasan Setu Babakan terbagi dalam 3 zona atau area:

- Zona A: pusat pelestarian pengembangan budaya dengan luas 3.2 hektar. Terdapat pengembangan berbagai rumah adat khas Betawi, museum sejarah dan purbakala, gedung teater dan gedung modern yang bernansa Betawi.

- Zona B: pusat kuliner Nusantara dengan tema Betawi untuk Indonesia. Zona ini memiliki luas sebesar 0.37 hektar. Terdapat lebih kurang 250 pedagang kuliner yang menjajakan makanan khas Betawi dan budaya Indonesia lainnya.

- Zona C: disebut zona komersial dan studi alam. Luas area ini sebesar 2.8 hektar. Terdapat replika perkampungan Betawi yang dilengkapi rumah adat, sawah dan empang atau danau kecil

Menarik untuk melihat bagaimana terpaan media dan daya tarik destinasi wisata Setu Babakan terhadap minat berwisata.

Media adalah sarana atau alat yang digunakan untuk membawa pesan dari sumber ke penerima. Dalam suatu peristiwa komunikasi, banyak saluran yang digunakan, meskipun hanya satu yang dominan. Dalam komunikasi massa, media berperan penting dalam penyampaian informasi ke khalayak luas sehingga media yang digunakan biasanya disebut media massa. Beberapa contoh media massa adalah surat kabar, majalah, televisi, radio, compact disk, video tape, buku dan juga internet (Nurudin, 2014:4-6).

Terpaan merupakan intensitas khalayak dimana terkena pesan- pesan yang disebarkan oleh suatu media. Menurut Ardianto (2014), terpaan dapat diartikan sebagai kegiatan mendengar, melihat, dan membaca pesan-pesan media ataupun mempunyai pengalaman dan perhatian terhadap pesan tersebut yang dapat terjadi pada individu atau kelompok. Terpaan media berusaha mencari data khalayak tentang penggunaan media baik jenis media, frekuensi penggunaan maupun durasi penggunaan. Penggunaan jenis media meliputi media audio, audiovisual, media cetak, dan media online.

Terpaan media dapat dilihat dari banyaknya informasi yang diperoleh khalayak melalui media, yang meliputi frekuensi, atensi dan durasi penggunaan pada setiap jenis media yang digunakan (Rosengren dalam Rakhmad, 2012) meliputi:

1) Frekuensi meliputi rutinitas atau berapa kali seseorang menggunakan media dan mengkonsumsi isi pesan dari media.

Penggunaan media mengumpulkan data khalayak tentang berapa kali sehari seseorang menggunakan media dalam satu minggu (untuk meneliti program harian), berapa kali seminggu seseorang menggunakan satu bulan (untuk meneliti program bulanan), serta berupa berapa kali sebulan seseorang menggunakan satu tahun (untuk meneliti program tahunan).

2) Durasi meliputi berapa lama seseorang menggunakan media dan mengkonsumsi isi pesan dari media Pengukuran variabel durasi penggunaan media menghitung berapa lama khalayak bergabung dengan suatu media (berapa jam 
sehari) atau berapa lama (menit) khalayak mengikuti suatu program.

3) Atensi merupakan tingkat perhatian yang diberikan seseorang dalam menggunakan media dan mengkonsumsi isi pesan dari media.

Daya tarik wisata menjadi faktor penting dalam mempengaruhi pilihan wisatawan untuk mengunjungi destinasi wisata selain terpaan media. Kepuasan wisatawan setelah mengunjungi destinasi wisata merupakan syarat untuk menjaga keberlanjutan destinasi wisata. Wisatawan yang merasa puas dengan pengalaman berwisatanya akan memiliki kecenderungan untuk kembali berkunjung dan merekomendasikan destinasi tersebut kepada orang lain.

Destinasi pariwisata sering disebut dengan daerah tujuan wisata adalah kawasan geografis yang berada dalam satu atau lebih wilayah administratif yang di dalamnya terdapat daya tarik, fasilitas umum, fasilitas pariwisata, aksesibilitas, serta masyarakat yang saling melengkapi terwujudnya kepariwisataan. Menurut Undang-Undang Nomor 10 tahun 2009 tentang Kepariwisataan pada Bab I Pasal 1 destinasi wisata adalah suatu tempat atau wilayah yang tidak selalu identik dengan wilayah administratif, tatapi lebih mengarah pada konstruk mental, besifat dinamik, sesuai dengan hubungan antara masyarakat dengan lingkungan yang membentuk tempat tersebut dan terbentuk karena karakteristik spesial, temporal, dan sosio kultural, serta memiliki nama dan makna, sehingga memiliki citra tertentu. Didalamnya, tercantum komponen-komponen produk wisata, antara lain daya tarik, pelayanan, dan sumber daya wisata lainnya.

Berdasarkan Undang-Undang Republik Indonesia No. 10 tahun 2009 Tentang kepariwisataan, Daerah tujuan pariwisata yang selanjutnya disebut Destinasi Pariwisata adalah kawasan geografis yang berada dalam satu atau lebih wilayah administratif yang didalamnya terdapat daya tarik wisata, fasilitas umum, fasilitas pariwista, aksesibilitas, serta masyarakat yang saling terkait dan melengkapi terwujudnya kepariwisataan.

Daya tarik Wisata menurut UndangUndang No. 10 Tahun 2009 tentang Kepariwisataan pasal 1 ayat 5, adalah segala sesuatu yang memiliki keunikan, keindahan, dan nilai yang berupa keanekaragaman kekayaan alam, budaya, dan hasil buatan manusia yang menjadi sasaran atau tujuan kunjungan wisatawan. Daya tarik wisata dikelompokan menjadi tiga yaitu daya tarik alam, daya tarik budaya dan daya tarik buatan.

Daya tarik wisata dikatakan juga sebagai destinasi wisata atau obyek wisata menurut Wardiyanta (2010) dibedakan menjadi tiga yaitu:

1) berasal dari alam, misalnya pantai, pemandangan alam, pegunungan, hutan, dan lain-lain.

2) hasil budaya, misalnya museum, candi, dan galeri.

3) kegiatan keseharian masyarakat, misalnya tarian, karnaval, dan lainlain.

Obyek wisata merupakan potensi yang menjadi pendorong kehadiran wisatawan ke suatu daerah tujuan wisata.

Obyek wisata harus dirancang, dibangun dan dikelola secara profesional sehingga dapat menjadi distinasi atau daerah tujuan wisata yang menarik wisatawan untuk datang ke obyek wisata tersebut. Pengembangan destinasi wisata menurut Suwantoro (2004) melibatkan stakeholder, pemerintah, dan kalangan masyarakat umum (lokal). Pengembangan daerah tujuan wisata yang baik akan dapat memudahkan akses wisatawan mencapai 
distinasi wisata. Pengembangan destinasi wisata dapat dilakukan melalui pendekatan faktor demand (pengunjung) dan supply yaitu attraction, accessibilty, amenity, ancillary (4A).

Attractions wisata menurut Suwena (2010) merupakan komponen yang signifikan dalam menarik kedatangan wisatawan. Hal yang dapat dikembangkan menjadi atraksi wisata disebut dengan modal atau sumber kepariwisataan (tourism resources). Modal atraksi yang menarik kedatangan wisatawan ada tiga, yaitu natural Resources (alami) seperti gunung, danau, pantai dan bukit; atraksi wisata budaya seperti arsitektur rumah tradisional di desa, situsarkeologi, seni dan kerajinan, ritual, festival, kehidupan masyarakat sehari-hari, keramahtamahan, makanan; dan atraksi buatan seperti acara olahraga, berbelanja, pameran, konferensi dan lain-lain. Modal kepariwisataan dapat dikembangkan menjadi atraksi wisata di tempat modal wisata ditemukan (in situ) dan di luar tempatnya yang asli (ex situ). Atraksi wisata dibedakan lagi menjadi atraksi penahan dan atraksi penangkap wisatawan.

Minat menurut Aprilia (2015) adalah dorongan atau rangsangan internal yang memotivasi tindakan, dimana dorongan dipengaruhi oleh stimulus dan perasan positif akan produk atau jasa. Minat atau perhatian adalah kecenderungan bertingkah laku yang terarah terhadap kegiatan objek kegiatan atau pengalaman tertentu. Minat mempunyai hubungan dengan intensionalitas, yaitu keterarahan dan pengarahan sebagai tanda penting bagi semua gejala hidup. Kecenderungan ini berbeda dalam intensitasnya pada setiap individu (Nuraeni, 2014).

Minat menurut Dharmmesta (2008) diartikan sebagai teknik yang didasarkan pada asumsi kesukaan konsumen terhadap merk, pangsa pasar, serta kemauan untuk membeli. Konsumen melakukan pilihan berdasarkan keinginan untuk mengambil pilihan/membeli sesuatu. Minat merupakan motifasi yang mendorong orang untuk melakukan apa yang diinginkan. Bila sesuatu menyenangkan atau menguntungkan, akan menumbuhkan minat dan mendatangkan kepuasan, bila kepuasan berkurang maka minat pun ikut berkurang.

Minat berwisata menurut Ramadhan (2015) adalah dorongan dari dalam diri konsumen berupa keinginan untuk mengunjungi suatu tempat atau wilayah yang menarik perhatian seseorang. Minat pembelian pada konsumen dapat disamakan dengan minat berkunjung pada wisatawan. Minat berkunjung disamakan dengan minat pembelian yang diukur oleh indikator yang sama. (Kotler, 2006). Konsumen atau Wisatawan dalam memutuskan untuk berkunjung memiliki berbagai pertimbangan seperti halnya sebelum melakukan pembelian. Dalam proses untuk memilih, terdapat satu aspek dimana calon konsumen atau wisatawan dapat menentukan seperti apa tujuan dari pilihan yang ada dibenak konsumen atau wisatawan tersebut. Dorongan yang kuat dan memotivasi untuk memilih sebagai suatu tindakan inilah yang kemudian disebut dengan minat. Indikator yang digunakan untuk mengukur minat berkunjung adalah ketertarikan dan pencarian informasi. Jadi rumusan masalah dalam penelitian ini adalah bagaimana pengaruh terpaan media dan daya tarik destinasi wisata terhadap minat berwisata.

Manfaat akademis dari penelitian ini adalah memperkaya kajian penelitian komunikasi pariwisata. Sedangkan manfaat praktis adalah memberikan masukan bagi pegelola destinasi wisata Setu Babakan dalam mengelola informasi 
wisata melalui beragam teknologi komunikasi.

\section{Metode}

Pendekatan yang digunakan dalam penelitian ini adalah pendekatan kuantitatif yang dinyatakan sebagai paradigm positivistis. Pendekatan kuantitatif menekankan kuantifikasi pengumpulan dan analisis data dengan pendekatan deduktif untuk hubungan antara teori dan penelitian dengan menempatkan pengujian teori (testing of theory). Oleh karena itu, penelitian kuantitatif merupakan sebuah penyelidikan tentang masalah sosial berdasarkan pada pengujian sebuah teori yang terdiri dari variabel-variabel, diukur dengan angka, dan dianalisis dengan prosedur statistic untuk menentukan apakah generalisasi prediktif teori tersebut benar atau salah (Silalahi, 2012:76).

Penulis menggunakan pendekatan kuantitatif untuk mengukur pengaruh terpaan media dan daya tarik destinasi wisata terhadap minat berwisata.

Selain itu, jenis penelitian yang digunakan penulis adalah eksplanasi. Penelitian eksplanasi bertujuan untuk menjelaskan hubungan antara dua atau lebih gejala atau variabel. Ada dua tipe eksplanasi yaitu penelitian asosiasi dan penelitian kausal. Jadi, penelitian asosiasi dan penelitian kausal meliputi observasi nilai-nilai dari dua atau lebih variabel dan menentukan apakah ada hubungan di antara mereka (Silalahi, 2012:32). Pada penelitian ini, peneliti menggunakan jenis penelitian eksplanasi kausal karena ingin mengetahui pengaruh antara tiga variabel yaitu variabel terpaan media, daya tarik destinasi wisata dan minat berwisata.

Penelitian ini menggunakan metode survei. Survei adalah metode riset dengan menggunakan kuesioner sebagai instrumen pengumpulan datanya.
Tujuannya untuk memperoleh informasi dengan tentang sejumlah responden yang dianggap mewakili populasi tertentu. Secara umum metode survei terdiri dari survei deskriptif dan survei eksplanatif. Pembagian ini berdasarkan pada tataran atau cara periset menganalisis data yang telah dikumpulkan dan jumlah variabel yang diteliti (Kriyantono, 2012:59). Penelitian ini menganalisis data secara eksplanatif. Maka dari itu, jenis survei yang digunakan pada penelitian ini adalah survei eksplanatif. Jenis survei eksplanatif digunakan apabila peneliti ingin mengetahui mengapa situasi atau kondisi tertentu terjadi atau apa yang mempengaruhi terjadinya sesuatu. Peneliti tidak hanya sekedar menggambarkan terjadinya sebuah fenomena tapi telah mencoba menjelaskan kenapa fenomena terjadi dan apa pengaruhnya.

Populasi merupakan jumlah total dari seluruh unit atau elemen di mana peneliti melakukan penelitian. Populasi dapat berupa organisme, orang atau sekelompok orang, masyarakat, organisasi, benda, objek, peristiwa, atau laporan yang semuanya memiliki ciri dan harus didefinisikan secara spesifik dan tidak secara mendua (Silalahi, 2012:253). Populasi penelitian adalah wisatawan kawasan budaya Betawi Setu Babakan sejumlah 213.277.

Sampel adalah satu subset atau tiap bagian dari populasi berdasarkan apakah itu representatif atau tidak. Sampel merupakan bagian tertentu yang dipilih dari populasi. Hasil penelitian sampel dapat digunakan untuk menjelaskan atau menaksir (estimate) populasi (Silalahi, 2012:254). Jumlah sampel yang digunakan dalam penelitian di hitung dengan menggunakan rumus Slovin. Rumus Slovin digunakan untuk menentukan ukuran sampel dari populasi 
yang diketahui jumlahnya (Kriyantono, 2012:164). Untuk menentukan jumlah sampel dapat dihitung dengan menggunakan rumus:

Keterangan :

$$
n=\frac{N}{1+N e^{2}}
$$

$\mathrm{n}=$ ukuran sampel

$\mathrm{N}=$ ukuran populasi

e=kelonggaran ketidaktelitian karena kesalahan pengambilan sampel yang dapat ditolerir

$n=\frac{213.277}{1+213.277 \times(0.1)^{2}}$

$n=99.99$

*dibulatkan menjadi $n=100$ sampel

Jumlah sampel dalam penelitian ini sebanyak 100 orang dengan tingkat kesalahan yang ditolerir sebesar $10 \%$.

Dalam penelitian ini, penulis menggunakan teknik pengumpulan data dengan kuisioner. Kuisioner adalah satu set tulisan tentang pertanyaan yang diformulasi supaya responden mencatat jawabannya, biasanya secara terbuka alternatif jawaban ditentukan. Pertanyaan dalam seperangkat kuisioner ialah tentang indikator dari konsep (Silalahi, 2015:441). Kuesioner dalam penelitian ini menggunakan pengskalaan likert. Skala Likert banyak digunakan terutama untuk mengukur sikap, pendapat, atau persepsi sesorang tentaqng dirinya atau kelompoknya atau sekeelompk orang yang berhubungan dengan suatu hal. Skala ini sering disebut sebagai summated scale yang berisi sejumlah pernyataan dengan kategori respons (Silalahi, 2012:229). Kuisioner dalam penelitian menggunakan empat item respons, yaitu sangat tidak setuju, tidak setuju, setuju dan sangat setuju.

Pada penelitian ini, penulis tidak menggunakan jawaban netral. Jawaban netral mengakibatkan responden akan cenderung memilih jawaban ditengahtengah, terutama responden yang raguragu dalam memilih jawaban. Jawaban di tengah-tengah akan menghilangkan banyaknya data, sehingga data yang diperlukan banyak yang hilang (Kriyantono, 2012:88).

Hipotesis yang diajukan dalam penelitian ini adalah sebagai berikut:

Ho (Hipotesis Nol): Tidak ada pengaruh dari terpaan media dan daya tarik destinasi wisata terhadap minat berwisata

$\mathrm{H}_{1}$ (Hipotesis Alternatif): Ada pengaruh dari terpaan media dan daya tarik destinasi wisata terhadap minat berwisata

Pemrosesan data atau pengolahan data adalah proses mentransformasi (menyederhanakan dan mengorganisasi) data mentah ke dalam bentuk yang mudah dibaca dan dipahami (Silalahi 2012:20). Pada penelitian ini, penulis mengolah data menggunakan seluruh proses transformasi data, yaitu melalui kegiatan penyuntingan, pengkodean, dan tabulasi.

1) Penyuntingan: Penyuntingan merupakan proses memeriksa kembali kualitas data dalam instrumen. Beberapa hal yang diperiksa kembali adalah kelengkapan, akurasi, konsistensi, keseragaman, dan relevansi (Silalahi, 2012:322) .

2) Pengkodean: Pengkodean merupakan satu set aturan yang menyatakan bahwa angka tertentu diberikan untuk atribut variabel tertentu. Proses pengkodean dilakukan dengan mempelajari terlebih dahulu jawaban responden untuk tiap pertanyaan dan kategori-kategori yang digunakan, menentukan kode jawaban untuk tiap pertanyaan dank ode tersebut harus dipahami apakah berupa angka atau skor, dan yang terakhir adalah alokasi 
dari jawaban-jawaban individu ke dalamnya (Silalahi, 2012:323). Nilai respons untuk variabel juga dapat diekspresikan dalam bentuk string atau numeric. String variables menggunakan tulisan untuk mengindikasikan nilai, sedangkannumeric variable menggunakan angka (Silalahi, 2012:327). Dalam penelitian ini, data dikumpulkan melalui kuisioner yang disebar dengan nilai skor: Jawaban "sangat tidak setuju", skor 1. Jawaban "tidak setuju", skor 2. Jawaban "setuju", skor 3. Jawaban "sangat setuju", skor 4

3) Tabulasi: Tabulasi merupakan alat analisis atau sebagai alat untuk menyusun kategori ketika mengubah variabel rasio atau interval menjado variabel nominal atau ordinal atau berdasarkan indeks. Tabulasi digunakan untuk menciptakan statistic deskriptif (Silalahi, 2012:331). Menyusun data dalam satu tabel dari satu unsur pengamatan disebut tabulasi sederhana; sedangkan menyusun data dalam tabel dari dua atau lebih unsur pengamatan disebut tabulasi silang (Silalahi, 2012:521).

Penelitian ini menggunakan skala interval untuk mengetahui terpaan, daya tarik destinasi wisata dan minat berwisata melalui pengkategorian jawaban responden dari seluruh indikator dengan menggunakan rumus untuk mencari interval. Rumus yang digunakan adalah :

$$
\begin{aligned}
& i=\frac{\text { Data terting } i-\text { Data terendah }}{\text { Jumlah kelas interval }} \\
& i=\frac{4-1}{2} \\
& I=1,5 \\
& \text { Keterangan: }
\end{aligned}
$$

Interval 1,00- $\leq 2,50$ masuk dalam kategori citra negatif
Interval 2,51 - 4,00 masuk kedalam kategori citra positif

Analisis korelasi digunakan karena penelitian ini bertujuan untuk mengetahui pengaruh terpaan media dan daya tarik destinasi wisata terhadap minat berwisata. Uji analisis korelasi dilakukan dengan menggunakan rumus korelasi "Product moment". Kriteria penafsiran mengenai indeks korelasi menurut Kriyantono (2012:173):

Hasil $r$ antara $0,00-0,19=$ rendah sekali Hasil $r$ antara 0,20-0,39= rendah tapi pasti Hasil $r$ antara $0,40-0,70=$ cukup tinggi Hasil $r$ antara $0,71-0,90=$ tinggi Hasil r lebih dari 0,90 = sangat tinggi

Untuk mengetahui pengaruh antara dua variabel yaitu variabel $X_{1}$ terhadap variabel $Y$,dan $X_{2}$ terhadap Variabel $Y$ maka digunakan rumus regresi linier sederhana, dimana rumus ini digunakan untuk mengetahui pengaruh terpaan media dan daya tarik destinasi wisata terhadap minat berwisata. Perhitungan regresi akan dibantu dengan Statistical Package for Social Science (SPSS). Regresi linier sederhana memiliki rumus sebagai berikut :

$$
Y=a+b X
$$

Keterangan:

$Y=$ Variabel tidak bebas (subjek dalam variabel tidak bebas)

$X=$ Variabel bebas (subjek pada variabel independen yang punya nilai tertentu)

$a=$ nilai intercept (konstan) atau harga $Y$ bila $X=$ o

$b=$ koefisien regresi, yaitu amgka peningkatan atau penurunan variabel dependen yang didasarkan pada variabel independen. Bila $b(+)$ maka naik, bila b(-) maka terjadi penurunan.

Untuk menguji kebenaran dari hipotesis yang telah diajukan dalam penelitian ini maka digunakan uji t-test dengan rumus (Kriyantono, 2012: 177) : 


$$
t=\frac{r \sqrt{n}-2}{\sqrt{1}-r^{2}}
$$

Keterangan :

$t=$ uji statistik

$r=$ koefisien korelasi

Harga $\mathrm{t}$ diperoleh dari perhitungan menggunakan rumus diatas dengan harga $\mathrm{t}$ tabel dengan menentukan tingkat signifikansi uji dua pihak dan derajat kebebasan (n-2). Sujarweni (2015:148) menjelaskan beberapa cara untuk menarik kesimpulan diantaranya adalah jika sig > 0,05 maka Ho ditolak yang berati tidak adanya pengaruh antara terpaan media dan daya tarik destinasi wisata dengan minat berwisata, sedangkan jika sig < 0,05 maka Ho ditolak yang berarti adanya pengaruh antara terpaan media dan daya tarik wisata dengan minat berwisata. Sedangkan cara lainnya dengan melihat perbandingan $\mathrm{t}$ tabel. Jika $-\mathrm{t}$ tabel $<\mathrm{t}$ hitung < t tabel maka Ho diterima yang berarti tidak adanya pengaruh antara dua variabel sedangkan jika t hitung < - t tabel dan $\mathrm{t}$ hitung $>\mathrm{t}$ tabel maka Ho ditolak yang berarti adanya pengaruh antara variabel $X$ terhadap variabel $Y$.

Analisis data dilakukan dengan analisis distribusi frekuensi, analisis deskriptif mean dan analisis regresi berganda. Hasil penelitian bersifat deskriptif, empiris dan dapat digeneralisasi ke populasi yang lebih besar (Yunus Ulani, 2019) Penelitian ini bertujuan untuk mengetahui pengaruh terpaan media dan daya tarik destinasi wisata terhadap minat berwisata. Variable $\mathrm{X}_{1}$ terpaan media, variable $\mathrm{X}_{2}$ daya tarik destinasi wisata dan variable $Y$ minat berwisata. Penelitian dilakukan di Kawasan Wisata Perkampungan Budaya Betawi Setu Babakan Jakarta Selatan.

\section{Pembahasan}

Subyek penelitian adalah wisatawan kawasan Setu Babakan yang sebagian besar berasal dari Jakarta dan kota sekitarnya. Kawasan ini dibuka untuk dikunjungi wisatawan mulai pukul 08.0018.00. Wisata museum dimulai pukul 09.00-16.00. Wisata pertunjukan dimulai pukul 14.00-17.00.

Wisatawan yang berkunjung di Kawasan Setu Babakan ini tidak dikenakan biaya atau tarif masuk, namun hanya dikenakan biaya parkir kendaraan berkisar Rp. 2.000 hingga Rp. 5.000.

Terpaan media sebagai perilaku khalayak dalam menggunakan media, suatu kondisi di mana khalayak diterpa oleh isi media atau bagaimana isi media menerpa khalayak (Kriyantono, 2012). Penggunaan media terdiri dari jumlah waktu yang digunakan dalam berbagai media, jenis isi media yang dikonsumsi, dan hubungan antara individu dengan isi media yang dikonsumsi atau dengan media secara keseluruhan.

Hasil penelitian analisis diskriptif terpaan media berada pada kategori sedang. Hasil penelitian tingkat penggunaan atau terpaan media dapat dilihat pada tabel 1.

Tabel 1 Terpaan Media

\begin{tabular}{lcc}
\hline Kategori & $\mathbf{f}$ & Presentasi \\
\hline Tinggi & 19 & $19 \%$ \\
Sedang & 52 & $52 \%$ \\
Rendah & 29 & $29 \%$ \\
Jumlah & 100 & $100 \%$ \\
\hline \multicolumn{3}{c}{ Sumber: Hasil olahan peneliti }
\end{tabular}

Daya tarik wisata berupa objek wisata yang mempunyai daya tarik, keunikan dan nilai yang tinggi, yang menjadi tujuan wisatawan datang ke suatu daerah tertentu. Obyek wisata dapat menarik untuk dikunjungi wisatawan harus memenuhi syarat-syarat untuk pengembangan daerahnya yaitu 1) Something to see, di tempat tersebut harus ada obyek wisata dan atraksi wisata, yang berbeda dengan tempat lain. 2) Something to do, di tempat tersebut banyak yang dapat dilihat dan disaksikan. 3) Something 
to buy di tempat tersebut harus tersedia fasilitas untuk berbelanja, terutama barang-barang souvenir dan kerajinan rakyat sebagai oleh-oleh (Yoeti, 2008). Hasil penelitian daya tarik wisata yang berupa keunikan, keindahan, kekayaan alam serta fasilitas berada pada kategori tinggi. Hasil penelitian daya tarik destinasi wisata dapat terlihat dari Tabel 2.

Tabel 2 Daya Tarik Destinasi Wisata

\begin{tabular}{lcc}
\hline \multicolumn{1}{c}{ Kategori } & F & Presentasi \\
\hline Tinggi & 63 & $63 \%$ \\
Sedang & 34 & $34 \%$ \\
Rendah & 4 & $4 \%$ \\
Jumlah & 100 & $100 \%$ \\
\hline \multicolumn{2}{c}{ Sumber: Hasil olahan peneliti }
\end{tabular}

Minat berwisata yang berupa dorongan atau keinginan dari dalam diri konsumen/calon wisatawan untuk mengunjungi suatu tempat atau wilayah yang menarik perhatian berada pada kategori yang tinggi. Minat responden berwisata dapat dilihat dapat dilihat pada tabel 3 .

Tabel 3 Minat Wisata

\begin{tabular}{lcc}
\hline \multicolumn{1}{c}{ Kategori } & F & Presentasi \\
\hline Tinggi & 41 & $41 \%$ \\
Sedang & 27 & $27 \%$ \\
Rendah & 32 & $32 \%$ \\
Jumlah & 100 & $100 \%$ \\
\hline \multicolumn{2}{c}{ Sumber: Hasil olahan peneliti }
\end{tabular}

Tabel 4 Coefficients menunjukkan Pengaruh antara variable $\mathrm{X}_{1}$ terpaan media dan variable $X_{2}$ daya tarik secara parsial (sendiri sendiri) terhadap variable $Y$ minat berwisata. Nilai significan variable terpaan media $\left(\mathrm{X}_{1}\right)$ 0,130 lebih besar dari 0.05 dan nilai T hitung 1.52772 lebih lebih kecil dari T table $\mathbf{1 . 9 8 4 7 2}$ maka tidak terdapat pengaruh antara terpaan media dengan minat berwisata. Nilai significan variable daya tarik wisata (X2) 0,012 lebih kecil dari 0.05 dan $T$ hitung 2.823771 lebih besar nilai T table
1.98472 maka terdapat pengaruh antara daya tarik wisata dengan minat berwisata.

\begin{tabular}{|c|c|c|c|c|}
\hline & $\begin{array}{c}\text { Coeff } \\
\text { icient } \\
s\end{array}$ & $\begin{array}{c}\text { Standart } \\
\text { Error }\end{array}$ & $\begin{array}{c}T \\
\text { Stat }\end{array}$ & $\begin{array}{c}P- \\
\text { Value }\end{array}$ \\
\hline Intercept & $\begin{array}{l}1.024 \\
82721 \\
2\end{array}$ & 0.741096752 & $\begin{array}{l}1.382 \\
85\end{array}$ & 0.170 \\
\hline $\begin{array}{l}\text { X Variable } \\
1\end{array}$ & $\begin{array}{l}- \\
0.029 \\
6924 \\
32\end{array}$ & 0.019435759 & $\begin{array}{l}- \\
1.527 \\
72\end{array}$ & 0.130 \\
\hline $\begin{array}{l}\text { X Variable } \\
2\end{array}$ & $\begin{array}{l}0.063 \\
26470 \\
9\end{array}$ & $\begin{array}{l}0.02240433 \\
3\end{array}$ & $\begin{array}{l}2.823 \\
771\end{array}$ & 0.005 \\
\hline
\end{tabular}

Sumber: Hasil olahan penelitian

Tabel 5 menunjukkan pengaruh variable $X_{1}$ terpaan media dan variable $\mathrm{X}_{2}$ daya tarik wisata secara simultan (bersama sama) terhadap variable $\mathrm{Y}$ minat berwisata. Nilai significance sebesar 0.012 dan lebih kecil 0,05 yang berarti dan nilai $F$ hitung 4,548575 lebih besar dari $\mathrm{F}$ table yaitu 3,09 maka secara parsial terpaan media dan daya tarik destinasi wisata memberikan pengaruh yang signifikan terhadap minat wisatawan mengunjungi destinasi wisata.

Tabel 5 Daya Tarik Destinasi Wisata

\begin{tabular}{lccrcc}
\hline & $\boldsymbol{d} \boldsymbol{t}$ & SS & $\boldsymbol{M S}$ & $\boldsymbol{F}$ & $\begin{array}{c}\text { Significant } \\
\boldsymbol{F}\end{array}$ \\
\hline Regr & 2 & 13.049 & 6.52 & 4.54 & 0.012936 \\
essio & & 31496 & 46 & 8575 & \\
$\mathrm{n}$ & & & 57 & & \\
& & & & \\
Resi & 97 & 139.14 & 1.434 \\
dual & & 0685 & 44 \\
Total & 99 & 152.19 & & \\
\hline \multicolumn{5}{c}{ Sumber: Hasil olahan peneliti }
\end{tabular}

\section{Pembahasan}

Terpaan media berada pada kategori sedang $52 \%$ (tabel 1 ) hal ini 
menunjukkan bahwa pemanfaatan teknologi komunikasi dan informasi dalam industri pariwisata belum maksimal. Teknologi informasi belum secara penuh mengendalikan kehidupan masyarakat khususnya dalam bidang industri wisata.

Informasi global digital yearbook 2019 jumlah penduduk Indonesia sebesar 268.2 million, dari jumlah penduduk tersebut pengguna telepon seluler sebanyak $133 \%$ dari jumlah penduduk, penggunaan internet dan aktif dimedia social masing masing $56 \%$ (Hootsuite, 2019).

Perilaku seseorang dalam menggunakan media menurut Blumler dalam Little John (2009) dipengaruhi oleh beberapa faktor antara lain:

1) Surveillence, yaitu kebutuhan untuk mengetahui lingkungannya.

2) Curiosity, yaitu kebutuhan individu untuk mengetahui peristiwaperistiwa menonjol di lingkungannya.

3) Diversion, yaitu kebutuhan individu untuk lari dari perasaan tertekan, tidak aman, atau untuk melepaskan ketegangan jiwa.

4) Personal identity, yaitu kebutuhan individu untuk mengenal dirinya dan mengetahui posisi keberadaannya di masyarakat.

Pengguna telepon seluler di Indonesia melebihi jumlah penduduk di Indonesia. Namun pemanfaatannya lebih banyak untuk personal identity dengan aktif bermedia sosial.

Perubahan perilaku pasar dan konsumen pariwisata ke arah digital, meningkatkan jumlah penggunaan media. Penggunaan media dilakukan dari mencari berbagai informasi tentang destinasi wisata, informasi transportasi, akomodasi dan paket wisata, pemesan tiket, hotel. Informasi tersebut digunakan sebagai acuan dan sarana dalam berwisata. Berwisata sebagai bagian dari penentuan identitas diri seseorang.

Terpaan media berpengaruh terhadat minat masyarakat untuk mengunjungi destinasi wisata. meskipun pengaruhnya rendah. Terpaan media mampu mendorong kesadaran simbolik, kemudian kesadaran ini menimbulkan kesadaran konsumtif, dan kesadaran konsumtif menggiring konsumen pada kesadaran aktual/perilaku. (Widyatama R, 2009). Effendy (2013) mengatakan bahwa proses komunikasi massa dalam terpaan media akan menimbulkan efek tertentu. Efek yang ditimbulkan oleh proses komunikasi dalam terpaan media ada 3, yaitu efek kognitif, afektif dan behavioral.

Daya tarik wisata adalah segala sesuatu yang mempunyai daya tarik, keunikan, nilai yang tinggi, yang menjadi tujuan wisatawan datang ke suatu destinasi wisata.

Setiap destinasi wisata memiliki daya tarik tersendiri. Daya tarik wisata berupa daya tarik alam, daya tarik budaya maupun daya tarik buatan. Sebuah destinasi wisata bisa memiliki lebih dari satu daya tarik wisata misalnya daya tarik alam dan budaya. Daya tarik wisata adalah segala sesuatu yang menjadi daya tarik orang untuk mengunjungi suatu daerah tertentu (Yoeti, 2008). Daya tarik wisata adalah segala sesuatu yang menarik dan bernilai untuk dikunjungi dan dilihat. Daya tarik wisata adalah segala sesuatu yang mempunyai daya tarik, keunikan dan nilai yang tinggi yang menjadi tujuan wisatawan mengunjungi destinasi wisata. Daya tarik pariwisata adalah hal-hal yang menarik perhatian wisatawan yang dimiliki oleh daerah tujuan wisata, dengan 5 unsur penting destinasi wisata, yaitu: Attraction, Facilities, Infrastructure, Transportation, Hospitality (Spillane, 2002). 
Aksesibilitas adalah segenap sarana yang memberikan kemudahan kepada wisatawan untuk mencapai suatu destinasi maupun tujuan wisata. Faktor-faktor yang terkait dengan aspek aksesibilitas wisata meliputi petunjuk arah, bandara, terminal, waktu yang dibutuhkan, biaya perjalanan, frekuensi transportasi menuju lokasi wisata dan perangkat lainnya. Jarak dan waktu tempuh menuju destinasi. (Sunaryo, 2013).

Amenitas meliputi serangkaian fasilitas untuk memenuhi kebutuhan akomodasi (tempat penginapan), penyediaan makanan dan minuman, tempat hiburan tempat-tempat perbelanjaan dan layanan lainnya (Sugiama, 2011). Amenitas menurut French dalam Sunaryo (2013) bukan merupakan daya tarik bagi wisatawan, namun dengan kurangnya amenitas akan menjadikan wisatawan menghindari destinasi.

Ancillary service adalah ketersediaan sarana dan fasilitas umum yang digunakan oleh wisatawan yang juga mendukung terselenggaranya kegiatan wisata seperti bank, ATM, telekomunikasi, rumah sakit dan sebagainya (Sunaryo, 2013). Ancillary service mencakup keberadaan berbagai organisasi untuk memfasilitasi dan mendorong pengembangan serta pemasaran destinasi wisata (Sugiama, 2011).

Daya tarik wisata yang berupa keindahan dan keunikannya baik wisata alam, wisata budaya maupun wisata buatan. Destinasi wisata yang menarik didukung dengan fasilitas, infrastruktur yang baik serta sarana transfortasi yang memadai dan pelayanan yang baik menjadi magnet bagi wisatawan untuk berkunjung.

Minat berwisata berada pada kategori tinggi sebesar $41 \%$ (tabel 3 ). Minat berwisata perlu ditingkatkan sejalan dengan program kementrian pariwisata.
Target peningkatan wisatawan nusantara tahun 2019 sebesar 12,07\% dari capaian tahun 2018 sebesar 303.500.000 orang. Jumlah terus meningkat dari tahun 2017 sebesar 270.882.003 orang dan tahun 2016 sebesar 264.337.518 orang (Kemenpar, 2018).

Upaya yang telah dilakukan Kemenpar untuk meningkatkan pertumbuhan wisnus dengan 1) Pengembangan 10 Destinasi Pariwisata Prioritas baru yaitu Danau Toba, Tanjung Kelayang, Tanjung Lesung, Kepulauan Seribu dan Kota Tua Jakarta, Borobudur, Bromo-Tengger-Semeru, Mandalika, Labuan Bajo, Wakatobi dan Morotai. 2) Pengembangan Destinasi Digital Melibatkan generasi milenial dalam satu wadah komunitas yang tergabung dalam GENPI (Generasi Pesona Indonesia) dan GENWI (Generasi Wonderful Indonesia). Komunitas Genpi berfungsi untuk mem-viral-kan destinasi pariwisata yang ada di Indonesia serta menggerakan ekonomi kerakyatan melalui pasar digital. 3) Mengembangakan Nomadic Tourism atau wisata nomad. Wisata nomad adalah setiap kegiatan, bisnis yang menghubungkan gaya hidup nomaden (berpindah-pindah), menikmati produk destinasi, mendapatkan layanan dan pengalaman berwisata. Ciri dari wisatawan dengan kategori nomad ini adalah berumur di antara 35-55 tahun, pendidikan setara SMA sampai kuliah; memiliki pendapatan menengah dan tidak memiliki anak dibawah 12 tahun (UNWTO, 2016).

Nomadic tourism adalah gaya pariwisata baru, dimana wisatawan dapat menetap dalam kurun waktu tertentu disuatu destinasi wisata dengan amenitas yang mudah dipindahkan (portable) dan dapat berpindah-pindah (Kemenpar, 2018). Nomadic Tourism adalah kegiatan wisata yang dilakukan secara berpindahpindah dari satu tempat ke tempat lainnya, dilakukan oleh wisatawan usia 
produktif berusia 35-55 tahun, memiliki pendapatan menengah dan mengandalkan informasi terkini.

Tahun 2018 kementrian Pariwisata mencanangkan program digitalisasi destinasi dan wisata nomad sebagai upaya meningkatkan jumlah wisatawan. Beberapa tipe wisatawan nomad menurut Kemenpar (2018)

Glampacker, atau wisatawan dengan kategori 'millennial nomad. Wisatawan ini mengembara untuk melihat dunia yang 'instagrammable', atau wisatawan yang memanfaatkan digitalisasi dalam mendokumentasikan momen perjalanan ke media instagram maupun facebook. (2) Luxpacker, atau wisatawan dengan kategori "luxurious nomad' yaitu wisatawan yang melakukan perjalanan mengembara untuk melupakan dunia daerah asal mereka dengan menggunakan fasilitas media online. Wisatawan ini menggunakan fasilitas perjalanan dengan frekuensi tertentu di media Conde Nest travel, Expedia, booking.com, AirBnB, hotels.com, dan Agoda.com. (3) Flashpacker, atau wisatawan Digital Nomad yang menetap sementara pada suatu tempat, sembari bekerja darimana saja.

Nomadic tourism merupakan strategi membangun Attraction, amenities dan akses wisata dengan konsep nomadic atau nomaden. Nomadic tourism ttraction, adalah bentuk atraksi yang memberikan hiburan kepada wisatawan nomad. Atraksi hiburan dapat dikemas dari dari berbagai bentuk atraksi alam, buatan dan event. (2) Nomadic Tourism Amenities adalah ketersediaan akomodasi dalam bentuk caravan. (a) Caravan dapat berpindah pindah dan diberhentikan di destinasi wisata; (b) Glamping atau glamp-camp (glamour camping), yaitu fasilitas menginap dalam bentuk tenda yang mewah dengan fasilitas hotel bintang. (c) home-pod atau fasilitas akomodasi dalam bentuk rumah telur, yang dapat dipindahkan. (3) Nomadic tourism Access, adalah kemudahan yang diperoleh wisatawan nomad selama menuju ke destinasi dengan waktu yang lebih cepat. Alat yang dapat digunakan untuk memberi kemudahan wisatawan ke destinasi antara lain seaplane, helicity. Nomadic Tourism dilakukan di daerahdaerah yang minim fasilitas dan tidak memenuhi unsur $3 \mathrm{~A}$ (atraksi, amenitas, dan aksesibilitas). Konsep berpindah dan sementara dalam Nomadic Tourism, dapat mengatasi masalah keterbatasan amenitas pariwisata Indonesia. Nomadic Tourism, ditargetkan untuk semua wisatawan pada umumnya dan generasi milenial pada khususnya. Generasi milenial memiliki mobilitas yang tinggi, kebutuhan berwisata nomadic lebih besar. Generasi milenial yang suka wisata jumlahnya sangat besar dan sebagian besar adalah para backpacker. 4) melaksanakan Calender of event (COE) di 34 provinsi. COE diharapkan mampu meningkatkan jumlah wisatawan nusantara dan meningkatkan perekonomian masyrakat.

Terpaan media dan daya tarik destinasi wisata memberikan pengaruh yang signifikan terhadap minat mengunjungi destinasi wisata 0.012 (tabel 5). Hasil tersebut sejalan dengan laporan penelitian dari Centre for Strategic and International Studies (2018) yang menyatakan bahwa penggunaan media khususnya internet dan media sosial di Indonesia memberikan dampak positif bagi perkembangan wisata di Indonesia yang pada akhirnya akan meningkatkan perekonomian.

Daya tarik wisata berpengaruh terhadap minat berkunjung wisatawan. Daya tarik merupakan faktor terpenting dalam sistem pariwisata, dibandingkan 
dengan faktor lain yang membentuk produk pariwisata. Daya tarik sebagai sebuah produk pariwisata memiliki 5 unsur penting dalam suatu destinasi wisata, yaitu: Attraction, Facilities, accessibilty Infrastructure, Hospitality (Spillane, 2002). Atraksi wisata harus dipersiapkan terlebih dahulu agar dapat dinikmati wisatawan, no attraction, no destination. Fasilitas untuk memenuhi kebutuhan wisatawan berperan menunjang kemudahan dan kenyamanan wisatawan. Aksesibilitas memberikan kemudahan kepada wisatawan untuk mencapai suatu destinasi wisata. Aksesibilitas mendorong pasar potensial menjadi pasar nyata. Infrastruktur mendukung terselenggaranya kegiatan wisata. Pelayanan yang baik dapat mendorong pengembangan destinasi wisata.

Berbagai unsur produk wisata harus dapat dikemas menjadi satu produk wisata yang menarik. Daya tarik wisata merupakan pull factor yang mempengaruhi wisatawan dalam pengambilan keputusan mengunjungi destinasi wisata, Pengembangan destinasi wisata dapat dilakukan melalui pendekatan faktor demand (pengunjung) dan faktor supply (Suwantoro, 2004). Produk wisata sebagai faktor supply dalam pengembangan wisata, harus menarik sehingga dapat meningkatkan minat berkunjung wisatawan.

Faktor faktor yang mempengaruhi daya tarik wisata attraction, accessibilty, amenity, ancillary $(4 \mathrm{~A})$. Produk wisata harus dibuat menarik untuk meningkatkan minat konsumen/calon wisatawan mengujungi destinasi wisata. hal tersebut dikarenakan wisata merupakan produk jasa yang bersifat tidak berwujud, rapuh dan beragam. Sifat ini sangat mempengaruhi keputusan wisatawan untuk mengunjungi destinasi wisata.

Minat berkunjung tinggi sebanyak
41\% pada tabel 3 menunjukan masih perlunya upaya mendorong peningkatan minat calon wisatawan melakukan perjalanan wisata. calon wisatawan. Hasil tersebut tidak terlepas dari demografi responden yang $56 \%$ perempuan yang biasanya tidak suka melakukan perjalanan wisata dibandingkan dengan laki laki. Responden juga didominasi oleh pelajar dari sisi waktu sulit melakukan perjalanan diluar libur sekolah. Dari sisi keuangan pelajar belum memiliki penghasilan sehingga sangat tergantung pada keuangan orang tua.

Minat berwisata dipengaruhi bukan hanya terpaan media dan daya tarik wisata tapi juga faktor faktor yang lain. Model keputusan berwisata menurut Mascado dalam Cooper (1998) dipengaruhi oleh hubungan antara motivasi, dan psikologi sosial yang meliputi pengalaman wisatawan, siklus hidup, pendapatan, ketersediaan waktu, image destinasi dan pengalaman.

Perilaku konsumen merupakan faktor utama penopang aktivitas marketing yang dilaksanakan untuk menjual produk wisata. Perbedaan sikap, persepsi, motivasi berpengaruh dalam pembentukan minat berwisata. Model keputusan perjalanan wisata berdasarkan motivasi, keinginan, kebutuhan dan pengharapan secara personal dan social. Minat berwisata tetap dipengaruhi oleh stimuli yang didapatkan dari penggunaan/terpaan media. Pemeningkatan terpaan media berarti peningkatan stimulus, peningkatan stimulu meningkatkan minat berwisata. Semakin menarik destinasi wisata akan meningkatkan minat berwisata. Keputusan wisata dipengaruhi stimuli, determinasi perilaku, variable eksternal dan karakteristik atau daya tarik destinasi (Cooper, 1998). 


\section{Kesimpulan}

Berdasarkan analisis data penelitian yang dilakukan terhadap wisatawan dikawasan wisata budaya Betawi Setu Babakan maka hasil penelitian menunjukkan terpaan media berada pada kategori sedang. Hal ini menunjukan bahwa masyarakat belum secara maksimal menggunakan media untuk sarana berwisata. Teknologi informasi belum secara penuh mengendalikan sendi sendi kehidupan masyarakat khususnya dalam bidang industri wisata.

Daya tarik destinasi wisata berada kategori tinggi. Destinasi wisata yang menarik didukung fasilitas, infrastruktur, sarana transportasi dan pelayanan yang baik menjadi magnet bagi wisatawan untuk mengunjungi suatu destinasi.

Minat wisata pada kategori tinggi. Minat berwisata perlu ditingkatkan dengan mengembangkan destinasi wisata unggulan dan menarik. pengembangan destinasi digital, akses, fasilitas dan amenitas.

Terpaan media berpengaruh terhadat minat mengunjungi destinasi wisata. Terpaan media menimbulkan efek tertentu, baik efek kognitif, afektif maupun behavioral.

Terpaan media dan daya tarik wisata berpengaruh secara signifikan terhadap minat wisatawan. Minat berwisata dipengaruhi oleh stimuli berupa terpaan media. Pemeningkatan stimuli meningkatkan minat berwisata. Semakin menarik destinasi wisata akan meningkatkan minat berwisata. Keputusan berwisata dipengaruhi terpaan dan karakteristik atau daya tarik destinasi.

Saran akademis yang diberikan untuk penelitian lebih lanjut adalah dilakukan penelitian dengan pendekatan kualitatif dengan metode studi kasus untuk mengetahui strategi pengelolaan media dengan konten khusus mengenai wisata dan strategi promosi destinasi wisata dengan pemanfaatan teknologi komunikasi.

Saran praktis dari penelitian ini memberikan masukan bagi para pengelola destinasi wisata yaitu sebagai bahan pertimbangan dalam mempromosikan destinasi wisata melalui pemanfaataan teknologi.

\section{Referensi}

Aprilia, Fitri. (2015). Pengaruh Word of Mouth Terhadap Minat Berkunjung serta Dampaknya pada Keputusan Berkunjung (survey pengunjung Jawa Timur Park 2, Kota Batu), Jurnal Administrasi Bisnis, 24(1).

Ardianto, Elvinaro Komala Lukita, Karlinah Siti. (2014). Komunikasi Massa, Bandung, Sembiosa Rekatama Media, 168.

Centre for Strategic and International Studies (CSIS). (2018). Rich Interactive Applications (RIA) in Indonesia. Jakarta, CNBC Indonesia.

Cooper Chris, Flecter John, Gilbert David, Wanhill Stepen, Stephen Rebecca. (1998). Tourism Principle and Practice $2^{\text {th }}$ editions Harlow Enggland, Printice Hall.

Dharmmesta, BS. (2008). Manajemen

Pemasaran analisis perilaku konsumen, Yogyakarta, Badan

Penerbit Fakultas Ekonomi

Universitas Gajahmada. 40.

Effendy, Onong Uchjana. 2003. Ilmu, Teori dan Filsafat Komunikasi. Bandung, Remaja Rosdakarya

Hootsuite-We-are-Social-IndonesianDigital-Report. (2019). All The Data and Trends You Need to Understand Internet, Social Media, Mobile and E-Commerce Behaviours in 2019. 


\section{https://andi.link > Digital Marketing.}

Ismayanti, I. (2010). Pengantar

Pariwisata. Jakarta, Indonesia,

PT Grasindo.

Kemenpar, Kementerian Pariwisata RI.

(2018). Materi Rapat Kerja Nasional Pariwisata. Digitalisasi Destinasi dan Nomadic Tourism. 22 Maret. BNDCC Nusadua Bali.

Kotler, Philip. (2006). Manajemen Pemasaran, Edisi 1. Indonesia: PT. Indeks Kelompok. Gramedia :198.

Kriyantono, R. (2012). Teknik Praktik Riset Komunikasi edisi 6, Jakarta, Kencana Prenada Media Group, 207.

Laporan Akuntabilitas Laporan Kinerja Kementrian Pariwisata tahun 2018, www.kemenpar.go.id.

Little John, Stephen W \& Karen A. Foss.

(2009). Teori Komunikasi (Theories of Human Communication) Edisi 9. Jakarta: Salemba Humanika.

Nuraeni , Bellinda Sofa and Ferdinand, Augusty Tae and Sufan, Syuhada. (2014). Analisis FaktorFaktor Yang Mempengaruhi Minat Kunjung Ulang Wisatawan Museum Ranggawarsita Semarang. Semarang: Universitas Diponegoro. https://ejournal.undip.ac.id/index .php/jbs/article/view/14113 (diakses:12Mei 2019).

Nurudin (2014). Pengantar Komunikasi Massa. Jakarta: Rajawali Pers.

Nyoman, S. Pendit. (2002). Ilmu Pariwisata Edisi 7, Jakarta : Pradnya Paramita.

Rakhmat, J. (2012) Metode Penelitian Komunikasi, Bandung, Remaja Rosdakarya. 66.

Ramadhan, AH. (2015). pengaruh City branding terhadap minat berkunjung serta dampaknya pada keputusan berkunjung (survey pada wisatawan kota Surabaya ), Jurnal Administrasi Bisnis, 28 (2).

Silalahi, Ulber (2012). Metode Penelitian Sosial. Jakarta: PT Refika Aditama.

Spillane. (2002). Ekonomi Pariwisata Sejarah dan Prospeknya Yogyakarta: Kanisius.

Sugiama, AG. (2011). Pengembangan Pariwisata Berbasis Konservasi Alam, Bandung, Guardaya Intimarta. 17-18

Sugiyono, P. (2010). Metode Penelitian Kuantitatif. Kualitatif, dan $R \& D$, Bandung CV Alfabeta. 67.

Sunaryo, Bambang. (2013). Kebijakan Pembangunan Destinasi Pariwisata Konsep dan Aplikasinya di Indonesia. Yogyakarta: Gava Media. 159, 173.

Suwantoro, Gamal. (2004). Dasar-dasar Pariwisata. Yogyakarta: Andi Offset. 19.

Suwena, Widyatmaja. (2010). Pengetahuan Dasar Ilmu Pariwisata. Denpasar : Udayana University Press. 88-89

Uchjana, Effendy, Onong. (2013). Ilmu Komunikasi Teori dan Praktek,Bandung, PT, Remaja Rosdakarya.

Undang-Undang Republik Indonesia, Nomor 10 tahun 2009 tentang Kepariwisataan pada Bab I Pasal 1.

UNWTO. (2018). Press Release UNWTO and ATTA EDU Program; http://media.unwto.org/press- 
release/2014-11-04/unwto-and-

adventure-traveltrade-

association-release-global-

report-adventur.

Sugiyono $P$, 2010, Metode Penelitian Kuantitatif. Kualitatif, dan $R \& D$, Bandung CV Alfabeta : 67

UNWTO, Ganzukh. (2016). Nomadic Tourism for Mongolia. Critical Issues in Silk Road Tourism. http://cf.cdn.unwto.org/sites/all/f iles/pdf/3. gansukh_damba.pdf.

Yunus, Ulani. (2019). Digital Branding. Bandung : Simbiosa Rekatama
Media

Wardiyanta. (2010). Metode Penelitian Pariwisata. Yogyakarta : Penerbit Andi. 52.

Widyatama, Rendra. (2009). Pengantar Periklanan, Cetakan 6. Yogyakarta: Pustaka Book Publisher. 150.

Yoeti, Oka, A. (2008). Perencanaan dan Pengembangan

Pariwisata.Jakarta, Pradnya. Paramita.117. 